\title{
Difference in Immature Reticulocyte Fraction Percentage between Moderate and Severe Anemia in Transfusion-Dependent Thalassemia
}

\author{
Rizki Andriyani, Delita Prihatni, Ida Parwati, Tiene Rostini ${ }^{1}$ \\ Department of Clinical Pathology Faculty of Medicine Universitas Padjadjaran \\ Dr. Hasan Sadikin General Hospital Bandung, Indonesia
}

\begin{abstract}
Thalassemia is an inherited genetic disease caused by the disruption in globin chain synthesis. Inefective erythropoiesis in thalassemia leads to moderate to severe anemia, requiring routine blood transfusions. To evaluate erythropoiesis, immature reticulocyte fractions (IRF) can be measured using the hematology analyzer, avoiding the need of invasive bone marrow examination. The purpose of this study was to analyze the differences in the IRF percentage between moderate and severe anemia in transfusion-dependent thalassemia (TDT) patients. This was a cross-sectional comparative observational analytic study conducted at the Pediatric Thalassemia Clinic of Dr. Hasan Sadikin General Hospital Bandung in August-September 2020. The IRF was examined using the fluorescence flowcytometry method with whole blood sample added by EDTA anticoagulant. The statistical analysis used in this study was unpaired t-test and Mann Whitney's test. Subjects were 93 TDT pediatric patients, consisting of 48 boys (52\%) and 45 girls (48\%). The majority (72\%) of the patients had been diagnosed with thalassemia for more than 5 years with moderate anemia (40\%) and severe anemia (60\%). The median IRF percentage in moderate anemia was 6.4\% (range 0-22.7) while the range in severe anemia was $11.7 \%$ (range 4.1-35.8), suggesting a statistically significant difference $(\mathrm{p}<0.001)$ in the IRF percentage between moderate and severe anemia in transfusion-dependent thalassemia patients. To conclude, the more severe the anemia experienced by a thalassemia patient is, the higher the percentage of IRF.
\end{abstract}

Keywords: Anemia, erythropoiesis, IRF, transfusion dependent thalassemia

\section{Perbedaan Persentase Immature Reticulocyte Fraction antara Anemia Sedang dan Anemia Berat pada Transfusion Dependent Thalassemia}

\begin{abstract}
Abstrak
Talasemia merupakan penyakit genetik yang diturunkan yang mengakibatkan gangguan sintesis rantai globin. Hal ini menyebabkan eritropoesis inefektif sehingga terjadi anemia dengan derajat sedang hingga berat yang membutuhkan transfusi darah rutin (transfusion dependent thalassemia). Evaluasi eritropoesis dapat dilakukan melalui pemeriksaan immature reticulocyte fraction (IRF) menggunakan hematology analyzer sehingga tidak perlu melakukan pemeriksaan sumsum tulang yang invasif. Tujuan penelitian ini adalah mengetahui perbedaan persentase Immature Reticulocyte Fraction antara anemia sedang dengan anemia berat pada pasien transfusion dependent thalassemia (TDT). Penelitian ini berbentuk analitik observasional komparatif dengan rancangan penelitian potong lintang yang dilakukan di Poliklinik Anak Talasemia RSUP Dr. Hasan Sadikin Bandung pada bulan Agustus-September 2020. Bahan pemeriksaan yang digunakan adalah whole blood dengan antikoagulan EDTA untuk pemeriksaan IRF dengan metode pemeriksaan fluorescence flowcytometry. Analisis statistik menggunakan unpaired t-test dan Mann Whitney's test. Subjek penelitian adalah 93 pasien TDT yang terdiri dari 48 laki-laki (52\%) dan 45 perempuan (48\%), mayoritas subjek (72\%) telah terdiagnosis talasemia lebih dari 5 tahun dan dikategorikan ke kelompok anemia sedang (40\%) dan anemia berat (60\%). Median persentase IRF pada anemia sedang 6.4\% (0-22.7), anemia berat $11.7 \%(4.1-35.8),(\mathrm{p}<0.001)$. Terdapat perbedaan persentase IRF antara anemia sedang dan anemia berat pada pasien transfusion dependent thalassemia. Makin berat anemia pada pasien talasemia persentase IRF makin meningkat.
\end{abstract}

Kata kunci: Anemia, eritropoesis, IRF, transfusion dependent thalassemia

Corresponding author: Rizki Andriyani, Department of Clinical Pathology Faculty of Medicine Universitas Padjadjaran/Dr. Hasan Sadikin General Hospital Bandung Jl. Pasteur No. 38 Bandung, West Java, Indonesia, Email: kiky_14@yahoo.com 


\section{Introduction}

Thalassemia is a genetic disease that is inherited due to a mutation that causes disruption of globin chain synthesis. Thalassemia is found in the Mediterranean, Middle East, Indian subcontinent and Burma, southern China, Thailand, Malaysia, Pacific islands and Indonesia. Clinically, thalassemia is divided into thalassemia major, thalassemia intermedia and thalassemia minor. Based on transfusion requirement, thalassemia can be divided into transfusion dependent thalassemia and non transfusion dependent thalassemia. ${ }^{1}$

The imbalance of the $\alpha / \beta$ globin chain ratio due to unequal production of alpha or beta globin chains will lead to decreased survival of erythrocytes and their precursors. In $\beta$-thalassemia, excess $\alpha$ chains will cause oxidative stress and damage to cell membranes. This triggers apoptosis, the precursors of damaged erythrocytes are gradually phagocytes by activated macrophages in the bone marrow. ${ }^{2}$ Dyserythropoiesis in thalassemia patients is characterized by an increase in erythroid precursors and erythroid progenitor cells so that erythropoiesis becomes ineffective and results in anemia. ${ }^{3}$

Erythropoiesis activity can be assessed through reticulocyte examination in the peripheral blood, making it easier to do than bone marrow examination. Reticulocytes represent the regeneration of erythropoiesis where the number of reticulocytes in the blood represents a quantitative measurement of erythropoiesis while other reticulocyte parameters provide information about the quality of erythropoiesis. ${ }^{4,5}$

In addition to conventional reticulocyte measurements, the fluorescence flowsitometric method can divide reticulocytes into three stages of maturation. This maturation stage is determined by the RNA content in the reticulocytes, measured on an automatic hematology device as the fluorescence intensity. The more RNA content indicates younger reticulocytes. Immature reticulocyte fraction (IRF) is an early marker in evaluating regeneration of erythropoiesis. The percentage of IRF increases in just a few hours while reticulocyte levels increase after 2-3 days. Reticulocytes based on fluorescence intensity are divided into three categories representing different maturity stages, namely: 1) low fluorescence reticulocytes (LFR) or mature reticulocytes, 2) medium fluorescence reticulocytes (MFR) or semimature reticulocytes and 3) high fluorescence reticulocytes (HFR) or immature reticulocytes. This increase in young reticulocytes reflects regeneration from erythropoiesis. ${ }^{5,6}$

The purpose of this study was to explore whether there was a difference in the percentage of IRF between moderate anemia and severe anemia, and to assess erythropoietic activity in transfusion dependent thalassemia patients.

\section{Methods}

This study was an observational comparative analytic study with cross sectional design. The research was conducted at Pediatric Thalassemia Clinic of Hasan Sadikin Hospital Bandung and the Central Laboratory of Hasan Sadikin Hospital Bandung. The research was conducted from August 2020 to September 2020.

The subjects of this study were transfusion dependent thalassemia patients aged 1-18 years whose diagnosis had been confirmed by clinicians, from the Pediatric Thalassemia Clinic of Hasan Sadikin Hospital Bandung and met the inclusion criteria. The inclusion criteria in this study were transfusion dependent thalassemia patients whose diagnosis had been confirmed by the clinician, from the Pediatric Thalassemia Clinic of Hasan Sadikin Hospital Bandung. The subjects is divided into two groups based on WHO criteria for moderate and severe anemia. The exclusion criteria in this study were patient samples who were not eligible for reticulocyte examination such as clotted, hemolysis, overfilled or underfilled samples and TDT patients who had undergone splenectomy.

The sample used in this study was whole blood with EDTA anticoagulant for hemoglobin examination and reticulocyte parameters using hematology analyzer Sysmex XN-1000. Whole blood was derived from the subject's vein blood obtained through the phlebotomy procedure before the patient underwent transfusion and got informed consent from the parents or patients guardian.

Characteristics of research subjects in the form of categorical data presented in numbers and percentages. Meanwhile, the numerical data was tested for normality first by using the Shapiro-Wilk's test. Data analysis to test the difference in the percentage of IRF in transfusion dependent thalassemia patients with moderate and severe anemia using a comparative unpaired t-test if the data were normally distributed or the Mann Whitney's test if the data were not normally distributed. The result of statistical 
Tabel 1 Characteristic of Subjects

\begin{tabular}{|c|c|c|c|}
\hline \multirow{3}{*}{ Variable } & \multirow{2}{*}{$\begin{array}{l}\text { Total } \\
\mathrm{n}=93\end{array}$} & \multicolumn{2}{|c|}{ Group } \\
\hline & & $\begin{array}{c}\text { Moderate anemia } \\
\quad \mathbf{n}=37\end{array}$ & $\begin{array}{c}\begin{array}{c}\text { Severe anemia } \\
\mathrm{n}=56\end{array} \\
\end{array}$ \\
\hline & n (\%) & n (\%) & n (\%) \\
\hline \multicolumn{4}{|l|}{ Age (year) } \\
\hline$<5$ & $11(12)$ & $7(18.92)$ & $4(7)$ \\
\hline $5-18$ & $82(88)$ & $30(81.08)$ & $52(93)$ \\
\hline \multicolumn{4}{|l|}{ Gender } \\
\hline Male & $48(52)$ & $20(54)$ & $28(50)$ \\
\hline Female & $45(48)$ & $17(46)$ & $28(50)$ \\
\hline \multicolumn{4}{|c|}{ Thalassemia diagnosis (years) } \\
\hline$<5$ & $26(28)$ & $15(40.5)$ & $11(20)$ \\
\hline $5-10$ & $36(39)$ & $15(40.5)$ & $21(37)$ \\
\hline$>10$ & $31(33)$ & 7 (19) & $24(43)$ \\
\hline \multicolumn{4}{|c|}{ Blood transfusion interval (week) } \\
\hline 2 & $8(9)$ & $2(5)$ & $6(11)$ \\
\hline 3 & $46(49)$ & $18(49)$ & $28(50)$ \\
\hline 4 & $39(42)$ & $17(46)$ & $22(39)$ \\
\hline \multicolumn{4}{|l|}{ Blood component } \\
\hline PRC & $59(63)$ & $25(68)$ & $34(61)$ \\
\hline Leucoreduced-PRC & $34(37)$ & $12(32)$ & $22(39)$ \\
\hline Washed red cell & $0(0)$ & $0(0)$ & $0(0)$ \\
\hline \multicolumn{4}{|l|}{ Chelation } \\
\hline Oral & $92(99)$ & $36(97)$ & $56(100)$ \\
\hline Parenteral & $0(0)$ & $0(0)$ & $0(0)$ \\
\hline No & $1(1)$ & $1(3)$ & $0(0)$ \\
\hline
\end{tabular}

test is significant if $\mathrm{p}<0.05$. The analysis was performed using the Statistical Package for the Social Science (SPSS) program. This study was approved by the Health Research Ethics Committee of Dr. Hasan Sadikin General Hospital Bandung through the issuance of the ethical approval no. LB.02.01/X.6.5/260/2020.

\section{Results}

During the research subject collection period, 98 subjects met the inclusion criteria and were willing to take part in the research which was stated by the willingness of the subject's parents to sign an informed consent. From 98 subjects,
5 subjects were included in the exclusion criteria, 3 subjects because of clotted samples, 2 subjects because of other comorbidities besides thalassemia.

The characteristic data of research subjects included age, gender, duration of diagnosis of thalassemia, blood transfusion interval, types of blood components and types of chelation. Data on the characteristics of research subjects can be seen in Table 1 below.

In this study, we found that the median of IRF percentage in moderate anemia was $6.4 \%$ with range IRF percentage: $0-22.7 \%$ while in severe anemia was $11.7 \%$ with range IRF percentage 4.1-35.8\% depicted in Table 2.

In Table 2, it can be seen that the median of IRF

Table 2 Differences of Reticulocyte Maturation in TDT Patients with Moderate and Severe Anemia

\begin{tabular}{lccc}
\hline \multicolumn{1}{r}{ IRF percentage (\%) } & Moderate anemia & Severe anemia & P value \\
\hline Median & 6.40 & 11.7 & $<0.001^{*}$ \\
Range & $(0-22.7)$ & $(4.1-35.8)$ & \\
\hline
\end{tabular}


percentage in TDT patients with moderate and severe anemia different significantly $(p<0.001)$.

\section{Discussion}

Based on the literature search, this study is the first study to analyze the difference off IRF percentage in TDT patients with moderate and severe anemia. The subjects were 93 subjects, the majority of whom were in the 5-18 years age group with almost the same sex ratio of men and women ( $52 \%$ and $48 \%$ ). This is similar to data from the Center for Thalassemia, Department of Child Health, FKUI-RSCM in 2014, the most thalassemia patients were in the age range 6-14 years. Data from the Indonesian Thalassemia Foundation in 2014, the number of Thalassemia patients was 6,439 individuals with 3,219 male patients and 3,220 female patients. ${ }^{1}$

Transfusion in thalassemia patients is considered adequate if the pre-transfusion hemoglobin level is more than $9 \mathrm{~g} / \mathrm{dL}^{7,8}$ In this study only 11 subjects in the moderate anemia group had hemoglobin levels of more than $9 \mathrm{~g} /$ $\mathrm{dL}$, so that transfusions in the majority of study subjects were inadequate. Sari et al. in Jakarta in 2014 stated that blood transfusions and iron chelation therapy in thalassemia major patients in Indonesia were inadequate. This is due to financial problems to come to the hospital and low compliance in iron chelation therapy. ${ }^{9}$

The results of this study showed that the percentage of IRF was higher in the severe anemia group (median 11.7\%) than moderate anemia (median 6.4\%). The IRF percentage is the sum of the MFR and HFR percentages. The LFR percentage is obtained from the reduction of $100 \%$ with the IRF percentage, so the higher the IRF percentage, the lower the LFR percentage. Based on the literature search, there is no literature that compares IRF in thalassemia patients with moderate anemia and severe anemia. This increase in IRF indicates an erythropoiesis response from the bone marrow through accelerated release of immature reticulocytes. Decreased hemoglobin levels cause reduced oxygen to the tissues, this increases the secretion of erythropoietin from the kidneys. The hormone erythropoietin will stimulate red blood cell precursors in the bone marrow to release more red blood cells into the circulation so that more reticulocytes are found in peripheral blood. ${ }^{10}$ The results of this study indicate that a more severe degree of anemia will increase the percentage of immature reticulocytes in peripheral blood, so that the assessment of erythropoiesis can be seen through reticulocyte parameters.

The normal IRF value was 1.6-12.1\%. The mean age of the subjects in the study was 44 years with a range of age $13-80$ years. $^{1}$ According to the Sysmex journal, the normal IRF value for men and women is $1.6-10.5 \% .^{5}$ The results of this study showed that the median IRF in the moderate anemia group was $6.4 \%$ and the severe anemia group was $11.7 \%$. In patients with thalassemia reticulocytes only slightly increased, this is due to the apoptosis of red blood cell precursors in the bone marrow which causes ineffective erythropoiesis. ${ }^{2}$ This may explain why the IRF did not increase significantly in this study.

One of the study compared IRF in patients with thalassemia trait and iron deficiency anemia with normal people. The mean IRF of patients with thalassemia trait (8.7\%), normal people (4.4\%), mild iron deficiency anemia (12.9\%) and severe iron deficiency anemia (16.7\%). A moderate increase in IRF in thalassemia trait patients with chronically elevated erythropoiesis, suggests a defect in erythropoiesis in thalassemia. The expected IRF value is not as high as patients with iron deficiency anemia even with the same degree of anemia. This suggests an ineffective erythropoiesis in thalassemia, the important pathophysiological role played by the deposition of globin chains in erythroid precursors that leading to apoptosis. ${ }^{12,13}$

Limitation in this study, no screening was carried out on subjects with chronic kidney disease who had erythropoietin deficiency (chronic kidney disease stage 1-2) which could be a confounding factor in reticulocyte examination.

As conclusion, IRF percentage in TDT patients with moderate and severe anemia is different significantly $(\mathrm{p}<0,001)$, IRF percentage is higher in severe anemia. IRF can be used to evaluate erythropoietic response in TDT patients, but further study is still needed to compare with another types of anemia.

\section{References}

1. Kemenkes RI. Pedoman Pengendalian penyakit thalassemia di Fasilitas Kesehatan Tingkat Pertama. Jakarta: Kemenkes RI; 2017.

2. Keohane EM. Thalassemias. In: Keohane EM, Smith LJ, Walenga JM, editors. 
Rodak's hematology clinical principles and applications. $5^{\text {th }}$ ed. Missouri: Elsevier Saunders; 2016. p. 454-71.

3. Ribeil J-A, Arlet J-B, Dussiot M, Moura IC, Courtois G, Hermine O. Ineffective erythropoiesis in $\beta$-thalassemia. Sci World J. 2013;2013:1-7.

4. Urrechaga E, Borque L, Escanero JF. Analysis of reticulocyte parameters on the sysmex XE 5000 and LH 750 analyzers in the diagnosis of inefficient erythropoiesis. Int $\mathrm{J}$ Lab Hematol. 2011;33(1):37-44.

5. Haematology S. The importance of reticulocyte detection. Sysmex Educational Enhancement Development. 2016; 2016:18.

6. Piva E, Brugnara C, Spolaore F, Plebani M. Clinical utility of reticulocyte parameters. Clin Lab Med. 2015;35(1):133-63.

7. Sarkar T, Jana P, Maruthappapandian J, Das T, Adhikary M, Chellaiyan V, et al. A cross sectional study on adequacy of blood transfusion and transfusion related infections in thalassemic patients attending a medical college hospital, West Bengal. Int J Community Med Public Health. 2018 Aug;5(8):3596-99.

8. Cappellini MD, Porter JB, Viprakasit V, Taher AT. A paradigm shift on beta-thalassaemia treatment: How will we manage this old disease with new therapies?. Blood Rev. 2018;32(4):300-11.

9. Sari TT, Gatot D, Akib AAP, Bardosono S, Hadinegoro SRS, Harahap AR, et al. Immune response of thalassemia major patients in Indonesia with and without Splenectomy. Acta Med Indones-Indones J Intern Med. 2014;46:217-25.

10. Doig K. Erythrocyte Production and Destruction. In: Keohane EM, Smith LJ, Walenga JM, editors. Rodak's Hematology Clinical Principal and Applications. 5. th ed. Missouri: Elsevier Saunders; 2016. p. 95107.

11. Morkis IVC, Farias MG, Scotti L. Determination of reference ranges for immature platelet and reticulocyte fractions and reticulocyte hemoglobin equivalent. Rev Bras Hematol Hemoter. 2016;38(4):310-3.

12. Urrechaga E, Borque L, Escanero JF. Erythrocyte and reticulocyte parameters in iron deficiency and thalassemia. J Clin Lab Anal. 2011;25(3):223-8.

13. Urrechaga E, Borque L, Escanero J. Erythrocyte and reticulocyte indices in the assessment of erythropoiesis activity and iron availability. Int J Lab Hematol. 2013;35(2):144-9. 